\title{
Plant extract and essential oils added as antimicrobials to cheeses: a review
}

\author{
Fabiola dos Santos Gouvea ${ }^{1,2^{*}}$ Amauri Rosenthal ${ }^{2}$ Elisa Helena da Rocha Ferreira ${ }^{1}$
}

\footnotetext{
'Departamento de Tecnologia de Alimentos, Universidade Federal Rural do Rio de Janeiro (UFRRJ), 23890-000, Seropédica, RJ, Brasil. E-mail: fabiolagouv@gmail.com. *Corresponding author.

${ }^{2}$ Empresa Brasileira de Pesquisa Agropecuária, Embrapa Agroindústria de Alimentos, Rio de Janeiro, RJ, Brasil.
}

\begin{abstract}
Cheese is a food that is highly susceptible to contamination by pathogenic and spoilage microorganisms, which can result in a decrease in its shelf life and cause serious risks to the consumers' health. Consumers always require healthy food, free of synthetic preservatives, inducing a search for natural alternatives to ensure safety of the products. Essential oils and plant extracts emerge as an alternative for aiding cheese preservation. Some substances have demonstrated good effects against most pathogens and cheese spoilage microorganisms. However, intrinsic and extrinsic factors may influence the actions of these compounds when incorporated into cheese, besides affecting the product characteristics. This review aims at discussing the antimicrobial efficiency of plant extracts and essential oils as well as the impact of their incorporation on lactic bacteria and the sensory characteristics of products.

Key words: cheese, natural antimicrobial, essential oil, plant extract.
\end{abstract}

Extratos vegetais e óleos essenciais adicionados a queijos como antimicrobianos: uma revisão

RESUMO: O queijo é um alimento muito susceptível a contaminação por microrganismos patogênicos e deteriorantes, que podem ocasionar desde a diminuição da validade comercial até sérios riscos à saúde do consumidor. O consumidor vem demandando cada vez mais alimentos saudáveis e livres de conservantes sintéticos, induzindo à busca de alternativas naturais para garantir a segurança dos produtos. Os extratos de plantas e óleos essenciais surgem como alternativa promissora para auxiliar na conservação do produto, demonstrado boa eficiência contra os principais microrganismos patogênicos e deteriorantes do queijo. No entanto, fatores inerentes ao alimento, assim como fatores extrínsecos, podem influenciar na ação destes compostos quando incorporados ao queijo, além de impactar nas características do produto. Desta forma, esta revisão pretende analisar a eficiência antimicrobiana de extratos de plantas e óleos essenciais no queijo, bem como o impacto da sua incorporação nas bactérias ácido lácticas e nas características sensoriais do produto.

Palavras-chave: queijo, antimicrobiano natural, óleos essenciais, extratos de plantas.

\section{INTRODUCTION}

Cheese is a food consumed worldwide. Its production from different types of milk and technologies enables people to obtain hundreds of product varieties. Due to its pleasant taste, high biological protein value, and as it is perceived as a healthy food, its consumption has increased in recent years.

On account of the high-handling manufacturing process, inadequate cold chain, and ready-to-eat characteristics, cheeses are very susceptible to contamination by pathogenic and spoilage microorganisms, which can decrease the shelf life, entailing recalls, leading to a risk to the consumer's health. Among pathogens, Listeria monocytogenes,
Staphylococcus aureus, and Salmonella spp. are often associated with food outbreaks from the consumption of cheese (HASSANIEN et al., 2014).

Conversely, driven by the concern about health and well-being, consumers have demanded safer and healthier food, free of synthetic preservatives, which are often considered harmful and carcinogenic substances (MORO et al., 2015).

In order to meet the new demands from consumers and also increase market competitiveness through product differentiation, the food industry and research institutions have been looking for natural preservatives as alternatives to synthetic ones.

Aromatic and medicinal plants are already used in pharmaceutical industries for 
their active ingredients and in food industries as flavorings. More recently, because of the potential antimicrobial effect they have attracted the increased interest of food scientists and technologists (COSTA et al., 2015), as natural preservatives. Thus, the aim of this review lies in the potential effect of the addition of herbs, medicinal extracts, and essential oils to cheeses. They are added to act against major pathogens and spoilage microorganisms, as well as for their implication on the product's characteristics.

\section{Aromatic plants and essential oils}

Aromatic plants are defined as plant species with characteristic aromas and/or tastes, whose importance lies in having volatile components in denominated essential oils, with specific properties. These substances make them helpful to be used in different applications, for example, in comestic and pharmaceutical industries. These compounds are secondary metabolites that can accumulate in leaves, roots, flowers, and seeds (FORLIN, 2012). They commonly have biological functions in plants related to defense mechanisms against infections, excessive ultraviolet (UV), and herbivory (COSTA, 2015). Among aromatic plants, there are some subgroups of plants that include herbs and spices, which are used in food (LIBRAN et al., 2013). In recent years research has shown that these compounds may also have antimicrobial activity with potential application for food preservation (CALO, 2015).

Plant extracts are concentrated preparations of several possible compositions and consistencies, obtained from dried plant materials by steam distillation, cold pressing or solvent extraction, preceeded or not by pretreatments. The most common processes used for extraction may also involve maceration, infusion, decoction, digestion, percolation, distillation, and drying (FIB, 2010). Essential oils (EOs) are aromatic oily liquids constituted of a mixture of volatile compounds of low molecular weight groups, such as, terpenoids, phenylpropanoids, and sulfur- and nitrogencontaining compounds. Besides the traditional methods, new extraction methods such as ultrasonic, microwave, and supercritical fluid extraction have been investigated (DIMA \& DIMA, 2015).

In plant extracts and EOs, the components found in higher concentrations and related to antimicrobial activity are phenolic compounds, such as, thymol, eugenol, carvacrol, and also constituents such as linalool, sabinene, menthol, myrcene, and camphene (MORO et al., 2013; ASENSIO et al.,
2015), which explains their different antimicrobial and antifungal properties.

Concentration of these compounds in plant extracts and EOs are determined by genetics, however external factors such as climate and soil, plant management and phenological stage may change their concentration. These variations have been a limitation for the use of plant extracts and EOs in food, due to the lack of a standardized concentration of these bioactive compounds to be utilized from each plant source. Therefore, it is difficult to define and measure the specific quantity of plant material to be added, to ensure an expected antimicrobial effect in food, in addition to the need of analytical methods for a more accurate determination of these compounds (CALO et al., 2015).

Another important aspect in the use of plants and their constituents in food is the toxicity. Although, aromatic plants that can be used in food preparation have been applied for a long time, there is no typical toxicological information such as acceptable daily intake (ADI) or observed adverse effect (NEGI, 2012). Conversely, the EO herbs are usually classified as substances Generally Recognized as Safe (GRAS) (FDA, 2016).

\section{Mechanisms of action}

The mechanism of action of plant extracts and EOs have not been completely established yet. However, studies indicated that compounds of different chemical groups present in these natural products are generally able to act on more than one target in the cell, such as, in the permeabilization or disruption of the cytoplasmic membrane, allowing the passage of nonspecific compounds or the release of cytoplasmic contents, respectively (GILL \& HOLLEY, 2006a; ZHANG et al., 2016). In addition, they may inhibit the ATPase enzyme responsible for energy generation of the cell, leading to cell death (GILL \& HOLLEY, 2006b). DIAO et al. (2014) reported that the increase of concentration and treatment time with fennel seed EOs (Foeniculum vulgare Mill.) resulted in a proportional increase of the cell membrane permeability of Shigella dysenteriae, causing the release of intracellular compounds, especially potassium, calcium, and sodium ions. Leakage of cytoplasmic content was also observed in cells of Staphylococcus aureus and Escherichia coli exposed to cinnamon EO, being also observed as a correlation between the concentration of EO and the leakage increase of cytoplasmic content (ZHANG et al., 2016). BAJPAI et al. (2013) also reported that the accumulation of Cudrania triscupidata EO led to a 
significant release of cytoplasmic materials, including leakage of potassium ions responsible for the charge balance in the membrane, causing irreversible damage to Bacillus cereus and Escherich coli cells.

Incorporation of extracts and essential oils in cheese Extracts and EOs of aromatic and medicinal plants such as fennel, oregano, rosemary, dill, cumin, pepper, sage, thyme, and parsley demonstrated satisfactory in vitro antimicrobial activity against pathogens and spoilage microorganisms associated with cheese contamination (MORO et al.; CALEJA et al.; 2015; HASSANIEN et al., 2014) thus indicating great potential in their use as preservatives. However, the results obtained in vitro cannot be reported as strictly true for food due to the complexity of the food matrix, in which the intrinsic and extrinsic factors interfere with the activity of these compounds (CALO et al., 2015).

One of the intrinsic factors that undermines the effectiveness of these natural antimicrobial agents is the lipid content and protein present in food. These substances can wrap the surface of the microorganism, forming a physical barrier that prevents contact of the bioactive compound with the microorganism thus reducing the efficacy of the natural compound (FABBOOD et al., 1976). GUTIERREZ et al. (2008) evaluated the interference of lipid in the effectiveness of the EO antimicrobial activity of oregano and thyme in a media simulating a food matrix, and they reported that the addition of lipids in high concentrations reduced the inhibitory activity against Listeria monocytogenes. This effect was also reported by CAVA et al. (2007), who reported that the antimicrobial activities of cinnamon and clove EOs were lower in milk samples with higher fat content than in skim milk samples, thereby emphasizing the importance of evaluating the interaction of EOs and extracts with the composition of the product.

As cheese is a food with a high content of proteins and lipids, the concentrations of natural compounds to be added to achieve a particular amount of microbiological inhibition should possibly be greater than the ones tested in vitro (MORO et al. 2015). In accordance with such a proposition, GAMARIELLO et al. (2008) reported that the concentration of active compounds used to inhibit the growth of pathogenic microorganisms in cheese Fior di Latte was effectively higher than the level tested in vitro. A similar finding was reported by SHAN et al. (2011), who reported that the minimum inhibitory concentration of pomegranate EO against Listeria monocytogenes and Staphylococcus aureus, $10^{5} \mathrm{CFU}$
$\mathrm{mL}^{-1}$ each, was higher than $2.5 \mathrm{mg} \mathrm{mL}^{-1}$ in a culture medium, while the concentration of $40 \mathrm{mg} \mathrm{mL}^{-1}$ in Cheddar cheese failed to inhibit the same population of those microorganisms. In that study the EO was extracted from promegranate peel with ethanol $80 \%$ at room temperature.

In a similar manner, HASSANIEN et al. (2013) reported that the concentration of $0.1 \%$ black cumin EO resulted in the reduction of growth of $L$. mononocytogenes, S. aureus, E. coli, and Salmonella enteritidis in a culture medium, while in cheeses, such concentrations were not effective against $S$. aureus and L. monocytogenes. These results showed that the concentration of plant extracts required also varies according to the microorganism and their sensitivity to the active compounds.

Another factor to be considered in extrapolating the results of antimicrobial activity to real cheese is that this food contains all the necessary in vitro nutrients for microbial growth of the culture cell. This aspect coupled with a low content of water (substance required for the transportation of the natural compound to the microorganisms) compared to the culture media, allows faster recovery of cells damaged by natural antimicrobials (SMITHPALMER et al., 2001).

Beyond the inherent factors regarding the food composition, external factors such as packaging, storage temperature, concentration of the initial inoculums, and the type of microorganism can also interfere with the natural antimicrobial efficiency (BURT, 2004).

Stability of natural compounds must also be taken into account when they are added to food. Such compounds are usually sensitive to oxygen, light, temperature, and $\mathrm{pH}$ (DIMA \& DIMA, 2015) and may be lost during cheese processing. LIBRAN et al. (2013) observed a decrease in the content of compounds from Ocimum basilicum EOS (basil) and Tanacetum vulgare (tansy) added during the production of cheese. Similarly, MORO et al. (2015) reported that $37.49 \%$ of the total volatiles of rosemary EO (Rosmarinus officinalis) added to sheep milk were lost during cheese production, as a certain portion was lost in the whey. Thus, the concentration of plant extracts and EOs to be determined for incorporation into cheese must supply the possible losses during production and interaction with food, in order to provide adequate microbiological inhibition (HASSANIEN et al., 2014; MORO et al., 2015).

Hence, studies have been conducted in the food matrix to determine the minimum inhibitory concentration of EOs in foods (GUTIERREZ 
et al., 2008; TAYEL et al., 2015). In this sense, microencapsulation can also ensure better stability of these compounds during the processing and storage of cheeses, as well as, a gradual release of these antimicrobials during the shelf life of the product (CALEJA et al., 2015).

\section{Impact on the sensory properties of the cheese}

The addition of herbs and spices as flavoring in some varieties of cheeses is already a common practice. One of the most popular cheeses of Turkey named Van Herb, for instance, is produced with the addition of 25 different herbs (DAGDELEN et al., 2014). Therefore, the acceptance of cheese with EOs and extracts can be facilitated if consumers are already accustomed to this type of product. However, these components often have a strong flavor even when used in small concentrations, which can also cause a high sensory impact with possible rejection of the product, turning it into a limiting factor in the use of plants and their constituents (MORO et al., 2015). The acceptance of the product is extremely important because, just having a high antimicrobial effect is not sufficient if the consumer does not sensorially approve of it. Among the extracts of plants and EOs added to cheeses, oregano (GOVARIS et al., 2011), black cumin (HASSANIEN et al., 2014), green pepper (WHABA et al., 2010), rosemary, thyme, and grass lemon (TAYEL et al., 2016) resulted in good sensory acceptance.

To minimize the possible negative effects of plants and their constituents in the flavor of the products, a combination of different extracts and EOs has been investigated, which can result in a good antimicrobial effect at lower individual concentrations (GUTIERREZ et al., 2008). These combined compounds may have in some cases, a higher antimicrobial activity than when added separately, thus present a synergistic effect. However, it should be pointed out, as considered by BURT et al. (2004), that certain substances, even if present in low concentrations, may have a highy enhanced antimicrobial effect. GUTIERREZ et al. (2008) reported that a combination of EOs from oregano and thyme was more effective in the antimicrobial activity against pathogenic Bacillus cereus, Listeria monocytogenes, and Pseudomonas aeruginosa than when used singly. Futhermore, a combination of oregano and basil reduced the growth rate of Escherichia coli three times.

The combined use of these natural compounds with emerging technologies such as ultrasound, high pressure, and electric pulses can also potentially allow the use of lower concentrations of EOs, as such technologies commonly damage the cell membrane, thus facilitating cell penetration and action of antimicrobials (OLIVEIRA et al., 2015).

\section{Action against pathogenic microorganisms}

The recurrent food outbreaks associated with the consumption of cheeses make the control of contamination by pathogenic microorganisms the dairy's major concern. Therefore, the inhibition of pathogenic microorganisms commonly reported in cheeses such as L. monocytogenes, Staphylococcus aureus, Escherichia coli, and Salmonella spp by oils and extracts have been broadly investigated (HASSANIEN et al., 2014; CALEJA et al., 2014; CARVALHO et al., 2014; TAYEL et al., 2015). Reports on the antimicrobial activity of aromatic plants and EOs added to cheeses against pathogenic and spoilage microorganisms are displayed in table 1 .

Listeria monocytogenes is a Gram-positive psychotropic bacterium and has the ability to form biofilms that may persist for years on the surface of equipment and handling devices (CARVALHO et al., 2015). This bacterium is more severe in risk groups such as elderly people, pregnant women, and immunodeficients, being lethal in $30 \%$ of cases. The use of oils and extracts has provided anti-Listeria activity in cheeses. GOVARIS et al. (2011) evaluated the antimicrobial activity in Feta cheese with addition of EOs from oregano and thyme $\left(0.1 \mathrm{~mL} 100 \mathrm{~g}^{-1}\right.$ each $)$ on a population of two strains of $L$. monocytogenes (Scott A and LMK) for over 36 days of storage, under refrigeration at $4^{\circ} \mathrm{C}$. They observed reduction in a population of $10^{4} \mathrm{CFU} \mathrm{g}^{-1}$ to undetectable levels after 18 days of storage with the use of EOs from oregano. Results for thyme EOs were similar, being effective in the inhibition of the two strains of L. monocytogenes, which may be due to similar concentrations of the antimicrobial components present in both oils.

SHAN et al. (2011) reported that garlic extract also had a promising effect on the inhibition of L. monocytogenes, over nine days of storage, at room temperature. The microbial population reached its peak on the fifth day of storage and then was stable for a certain period, and finally decreased. At all stages, the population of this pathogen in Cheddar cheese with garlic extract was lower than in the control cheese. TAYEL et al. (2015) observed the effect of oregano, cinnamon, water cress, sage, rosemary, and lemon grass extracts in the reduction

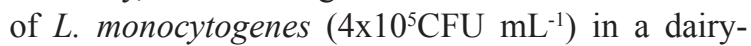
based-media and reported that all extracts inhibited the Listeria population. However, the cinnamon 
Table 1 - Antimicrobial actitivity of aromatic plants and essential oils added to cheeses.

\begin{tabular}{|c|c|c|c|}
\hline Cheese Type & $\begin{array}{l}\text { Natural antimicrobial (Source and } \\
\text { concentration) }\end{array}$ & $\begin{array}{c}\text { Inhibitory activity (microrganisms, counts, and storage } \\
\text { conditions) }\end{array}$ & Reference \\
\hline Feta & 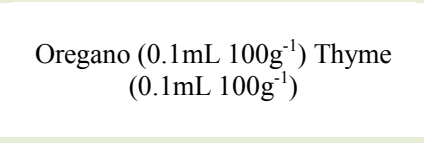 & $\begin{array}{l}\text { Inhibition of } L \text {. monocytogenes and } E \text {. coli } 0157: \mathrm{H} 7 \\
\text { population }\left(10^{4} \mathrm{CFU} \mathrm{g}^{-1}\right) \text { for } 18 \text { and } 22 \text { days, } \\
\text { respectively, after storage under modified atmosphere } \\
\text { packaging }\left(50 \% \text { de } \mathrm{CO}_{2} \text { e } 50 \% \text { de } \mathrm{N}_{2}\right) \text { at } 4^{\circ} \mathrm{C} \text {. }\end{array}$ & $\begin{array}{l}\text { GOVARIS et al. } \\
\qquad(2011)\end{array}$ \\
\hline Cheddar & $\begin{array}{l}\text { Garlic (dipping } 25 \mathrm{~g} \text { of cheese in } \\
100 \mathrm{~mL} \text { of plant extract solution). }\end{array}$ & $\begin{array}{c}\text { Inhibition of } L \text {. monocytogenes }\left(2 \log \mathrm{CFU} \mathrm{mL} \mathrm{m}^{-1}\right) \text { after } \\
\text { storage at } 23^{\circ} \mathrm{C} \text { for } 9 \text { days. }\end{array}$ & $\begin{array}{l}\text { SHAN et al. } \\
\quad(2011)\end{array}$ \\
\hline Kareich & $\begin{array}{c}\text { Cayenne }(3 \%) \text { or Green Pepper } \\
(9 \%)\end{array}$ & $\begin{array}{l}\text { Inhibition of } S \text {. aureus }\left(1 \times 10^{8} \mathrm{CFU} \mathrm{g}^{-1}\right) \text { to undetectable } \\
\text { levels within } 2 \text { days of storage at } 4^{\circ} \mathrm{C} \pm 2^{\circ} \mathrm{C} \text {. }\end{array}$ & $\begin{array}{l}\text { WAHBA et al. } \\
\qquad(2010)\end{array}$ \\
\hline Domiati & Black cumin seed oil $(0.1 \%$ e $0.2 \%)$ & 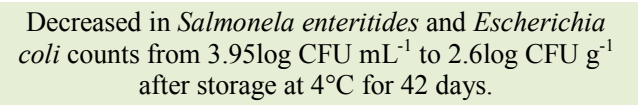 & $\begin{array}{l}\text { HASSANIEN et } \\
\text { al. (2014) }\end{array}$ \\
\hline Sheep's cheese & Rosemary essential oil $\left(215 \mathrm{mg} \mathrm{L}^{-1}\right)$ & $\begin{array}{l}\text { Prevented the growth of Clostridium spp. counts } 3 \log \\
\text { CFU g }{ }^{-1} \text { ripened for } 5 \text { months at } 12^{\circ} \mathrm{C}\end{array}$ & $\begin{array}{l}\text { MORO et al. } \\
\quad(2015)\end{array}$ \\
\hline $\begin{array}{l}\text { Coalho Cheese } \\
\text { mimicking } \\
\text { models }\end{array}$ & Thymus essential oils $\left(2.5 \mu \mathrm{L} \mathrm{mL}^{-1}\right)$ & 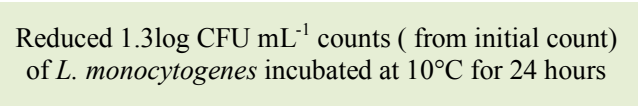 & $\begin{array}{l}\text { CARVALHO et al. } \\
\text { (2015) }\end{array}$ \\
\hline $\begin{array}{l}\text { Cheddar Based } \\
\text { Media }\end{array}$ & $\begin{array}{c}\text { Cinnamon }\left(400 \mu \mathrm{g} \mathrm{mL}^{-1}\right) \text { garlic } \\
\left(625 \mu \mathrm{g} \mathrm{mL}^{-1}\right), \text { lemon grass }(550 \mu \mathrm{g} \\
\left.\mathrm{mL}^{-1}\right), \text { cress }\left(475 \mu \mathrm{g} \mathrm{mL}^{-1}\right), \\
\text { rosemary }\left(750 \mu \mathrm{gL} \mathrm{mL}^{-1}\right), \text { sage } \\
\left(825 \mu \mathrm{g} \mathrm{mL}^{-1}\right) \text { and oregano extracts } \\
(950 \mu \mathrm{g} \mathrm{mL})\end{array}$ & $\begin{array}{l}\text { All extract concentrations individually inhibited the } \\
\text { population of } L \text {. monocytogenes }\left(4 \times 10^{5} \mathrm{CFU} \mathrm{mL}^{-1}\right) \\
\text { incubated at } 37^{\circ} \mathrm{C} \text { for } 24 \text { hours }\end{array}$ & $\begin{array}{l}\text { TAYEL et al. } \\
\qquad(2015)\end{array}$ \\
\hline Fior di Latte & $\begin{array}{l}\text { Thyme and sage essential oil } \\
\qquad\left(1500 \mathrm{mg} \mathrm{kg}^{-1}\right)\end{array}$ & $\begin{array}{l}\text { Inhibition of Pseudomonas spp and coliforms stored at } \\
\qquad 10^{\circ} \mathrm{C} \text { for } 6 \text { days }\end{array}$ & $\begin{array}{l}\text { GAMMARIELLO } \\
\text { et al. (2008) }\end{array}$ \\
\hline $\begin{array}{l}\text { Whey and } \\
\text { Requesón whey }\end{array}$ & Safranal $\left(35 \mu \mathrm{g} \mathrm{kg}^{-1}\right)$ & $\begin{array}{l}\text { Inhibited over } 15 \% \text { Penicillium verrucosum growth } \\
\text { (population of } 10^{5} \mathrm{CFU} \mathrm{mL} \mathrm{mL}^{-1} \text { of spore). }\end{array}$ & $\begin{array}{l}\text { LIBRÀN et al. } \\
\text { (2014) }\end{array}$ \\
\hline
\end{tabular}

extract was more efficient because it required a lower concentration $\left(400 \mu \mathrm{g} \mathrm{mL}^{-1}\right)$ to be effective, in comparison to the others EOs.

Staphylococcus aureus is a Gram-positive bacteria mainly reported in cheeses produced under poor hygiene conditions. This pathogen produces enterotoxin that can endanger the consumers' health, hence this has also been investigated in several studies with EOs. WAHBA et al. (2010) obtained a reduction in a population of $8 \log \mathrm{CFU} \mathrm{mL} \mathrm{m}^{-1}$ of $S$. aureus to undetectable levels in two days with the use of cayenne pepper and green pepper EOs in Kareich cheese, both in concentrations of $3 \%$. CARVALHO et al. (2015) were able to reduce the population of $S$. aureus in one cycle, in Cottage cheese, by using thyme EO with a concentration of $2.5 \mu \mathrm{L} \mathrm{mL}^{-1}$.

\section{Escherichia coli 0157:H7 and Salmonella} spp, both Gram-negative bacteria, have been seen to be more resistant to EOs (GOVARIS et al., 2011; SHAN, 2011). These observations are in agreement with other studies that demonstrate the lower antimicrobial efficacy of natural compounds in Gram-negative bacteria, their increased resitance being mainly attributed to the cell wall structure (DAGDELEN et al.,
2014; CALLUS et al., 2015). However, HASSANIEN et al. (2014) observed that the EO from black cumin seed at concentrations of $0.1 \%$ and $0.2 \%$ did not significantly reduce the population of $L$. monocytogenes and S. aureus (Gram-positive); whereas, these same concentrations significantly reduced populations of $S$. enteritides and E. coli (Gram-negative). TAYEL et al. (2015) observed the occurrence of close minimum inhibitory concentrations of oregano EO in dairy-based media to L. monocytogenes $\left(950 \mu \mathrm{g} \mathrm{mL}^{-1}\right)$, E. coli 0157: $H 7\left(975 \mathrm{~mL}^{-1}\right)$, and Salmonella typhimurium $(900 \mu \mathrm{g}$ $\left.\mathrm{mL}^{-1}\right)$, regardless of the Gram classification.

The growth of unwanted mold species is responsible for many sensory defects in cheeses, such as off-flavors and changes in texture and color. Moreover, the production of mycotoxins may represent a hazard besides decreasing the shelf life of the products, making it a challenge to find nontoxic antifungal substances for humans (LIBRAN et al., 2014).

Accordingly, some natural plant compounds have demonstrated promising results in inhibiting the growth of fungi. MORO et al. (2013) evaluated the in vitro antifungal activity of aromatic 
plants in cheeses, as inhibitors of Penicillium verrucosum growth, a deteriorating agent that acts on the surface of ripening cheese and is responsible for the production of an important mycotoxin named ochratoxin. The authors observed that at concentrations below $0.02 \mu \mathrm{L} \mathrm{mL}^{-1}$ of dill (Anethum graveolens) or hyssop (Hyssopus officinalis) EOs showed $50 \%$ inhibition in the growth of Penicillium verrucosum. ELGUEA-CULEBRAS et al. (2016) observed that the extract of Hyssopus officinalis agroindustrial solid residue also had the potential to control the growth of Penicillium verrucosum during cheese ripening. The concentration of solid residue that was required to inhibit $50 \%$ of the growth of Penicillium verrucosum was $92 \mu \mathrm{g} \mathrm{mL}^{-1}$. LIBRAN et al. (2014) observed a synergistic effect between saffron $\left(35 \mu \mathrm{L} \mathrm{mL}^{-1}\right)$ and whey in the inhibition of $P$. verrucosum, higher than the pure substance at the same concentration, and suggested that milk had components that enhanced the saffron effect. BALAGUER et al. (2013), conversely, reported that the incorporation of $5 \%$ cinnamaldehyde (compound present in cinnamon EO) into a film that coated a cheese spread delayed the growth of fungi Apergillus niger and Penicillium expansum within 10 storage days.

Besides inhibiting the growth of fungi, EOs have also been associated with delaying or even preventing the production of mycotoxins. Thus, VAZQUEZ et al. (2001) reported that the addition of eugenol at $200 \mu \mathrm{L} \mathrm{mL}^{-1}$ prevented the production of citrinin, a toxin produced by Penicillium citrinum, in cheese Arzúa Ulloa. GANDOMI et al. (2009) observed the suppression of the production of aflatoxins by EO of Zataria multiflora Boiss, a typical Iranian plant, in white Iranian ultrafiltrated cheese immersed in brine, and suggested that this EO prevented the growth of fungal micelles, as well as, the remaining fungi had the ability to produce aflatoxins. SINDHU et al. (2011) also reported the inhibition of aflatoxin production by EOs extracted from Curcuma (Curcuma longa L.) leaves at a concentration of $1.5 \%(\mathrm{v} / \mathrm{v})$.

\section{Effect of plant extracts and essential oils on beneficial bacteria cheese}

One of the technological implications of the addition of EOs to cheese is the possible inhibition of its natural microbial population or artificial starter cultures added to the product. The natural cheese microflora and starter cultures are responsible for fermentation and giving the desired sensory characteristics to the product.
The lactic acid bacteria reported in cheese have demonstrated their resistance to plant extracts and EOs at concentrations that inhibit the growth of pathogenic microorganisms. MORO et al. (2015) reported that the addition of EOs from rosemary prevented the growth of Clostridium tyrobutyricum in sheep's cheese, even though it did not reduce the population of lactic acid bacteria. GAMMARIELLO et al. (2008) reported a similar check in a study in which 13 plant extracts and EOs of orange species, grapefruit, spring lemon, parsley, and lemon Boyajian did not affect the survival of lactic acid bacteria in cheese Fior di Latte, although they decreased the population of the pathogenic bacteria.

The lactic acid bacteria also contribute to the safety of the cheese by competing with the pathogenic microorganisms and maintening a low pH (CARVALHO et al., 2015). Some studies have demonstrated that certain plant extracts and certain EOs do not significantly affect the $\mathrm{pH}$ of cheese or rather assist in maintaining a suitable $\mathrm{pH}$. In this sense, SHAN et al. (2011) reported that the addition of garlic extract maintained the $\mathrm{pH}$ of Cheddar cheese stable for nine days of the storage period, meanwhile in the control cheese there was a significant increase in the $\mathrm{pH}$ value. GAMMARIELLO et al. (2008) also reported that sage and thyme added to the Fior di Latte cheese did not cause significant reduction in a $\mathrm{pH}$ that ranged from 5.4 to 5.8. HAN et al. (2011) reported only a slight reduction in the milk $\mathrm{pH}$ with the incorporation of phenolic compounds derived from green tea, grape, and cranberry extracts, and suggested that these compounds contain organic acids and phosphates that can reduce the $\mathrm{pH}$. MARCIAL et al. (2016) reported that the manufacturing of a traditional Argentinean cheese added with $200 \mathrm{mg}$ $\mathrm{kg}^{-1}$ of oregano (Origanum vulgare var. hirtum) EO did not affect the growth or acidifying activity of lact acid bacteria Lactococcus lactis subsp. lactis, Lactobacillus delbrueckii subsp. Bulgaricus, and Streptococcus thermophilus, compared to the control cheese. However, CARVALHO et al. (2015) suggested that depending on the concentration, these natural compounds could inhibit the growth of lactic acid bacteria, leading to cheese $\mathrm{pH}$ elevation. The authors reported that the concentration of $2.5 \mu \mathrm{L}$ $\mathrm{mL}^{-1}$ of thyme EO added to a broth with a Coalho cheese base caused a slight decrease in the viable cell count of L. monocytogenes (1.3log CFU mL $\mathrm{m}^{-1}$ ) after 24 hours of exposure. The same concentration of thyme EO markedly reduced the counting of starter cultures composed of Lactococcus lactis subsp cremoris and Lactococcus lactis subsp. lactis

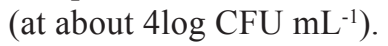




\section{CONCLUSION}

Some extracts and essential oils from plants have proved to be natural preservatives with significant inhibitory activity against major pathogens and spoilage microrganisms in cheeses. However, considering the losses during processing and their stability during storage, more studies should be performed to determine the concentration of the extracts and EOs that are required to be incorporated into cheeses, as well as the action of these natural antimicrobials on lactic acid bacteria.

Furthers studies are also necessary with regard to the association and different combinations of various EOs and plant extracts as well as with other ingredients, aiming to characterize the type of interaction concerning synergistic, antagonistic or additive effects. The increase in the quality of plant extracts and essential oils is also an important requirement for the use of these compounds by the food industry. It is necessary to cultive and stantardize plant material germoplasms with the aim of obtaining specific compounds or essential oil compositions. It is also necessary to enhance knowledge of the influence of plant, post-harvest, and agroindustrial management in the composition and final content of the chemical components, in order to minimize undesirable variation or the low effectiveness of these compounds in the products. Finally, it is necessary to broaden and deepen the sensory studies related to the utilization of individual and combined EOs and plant extracts in different types of cheeses in order to better understand the possible impacts on consumer acceptance.

\section{ACKNOWLEDGEMENTS}

The authors are grateful to Comissão de Aperfeiçoamento de Pessoal do Nível Superior (CAPES) for the Master Schorlarship to F.S.Gouvea; Embrapa (Project 02.11.07.020.00.00); Fundação Carlos Chagas Filho de Amparo à Pesquisa do Estado do Rio de Janeiro (FAPERJ), Program Scientist of Our State for A Rosenthal; Conselho Nacional de Desenvolvimento Científico e Tecnológico (CNPq) for the productivity scholarship (A Rosenthal).

\section{REFERENCES}

ASENSIO, C.M. et al. Quality preservation of organic cottage cheese using oregano essential oils. LWT- Food science and Tecnhology, v.60, p.664-671, 2015. Available from: <http:// www.sciencedirect.com/science/article/pii/S0023643814006896>. Accessed: Nov. 06, 2015. doi: 10.1016/j.1wt.2014.10.054.
BAJPAI, V.K. et al. Antibacterial mode of action of Cudrania tricuspidata fruit essential oil, affecting membrane permeability and surface characteristics of foodborne pathogens. Food Control, v.32, p.582-590, 2013. Available from: <http://www.sciencedirect. com/science/article/pii/S0956713513000558>. Accessed: Nov. 18, 2015. doi: 10.1016/j.foodcont.2013.01.032.

BALAGUER, M.P. et al. Antifungal properties of gliadin films incorporating cinnamaldehyde and application in active food packaging of bread and cheese spread food stuffs. International Journal of Food Microbiology, v.166, p.369-377, 2013. Available from: $<$ http://www.sciencedirect.com/science/article/pii/ S0168160513003863>. Accessed: Nov. 13, 2015. doi: 10.1016/j. ijfoodmicro.2013.08.012.

BURT, S. Essential oils: their antibacterial properties and potencial applications in foods- a review. International Journal of Food and Microbiology, v.94, p.223-253, 2004. Available from: <http:// www.sciencedirect.com/science/article/pii/S0168160504001680>. Accessed: Nov. 06, 2015. doi: 10.1016/j.ijfoodmicro.2004.03.022.

CALEJA, C. et al. Foeniculum vulgare Mill. as natural conservation enhancer and healh promoter by incorporation in cottage cheese. Journal of Functional Foods, v.12, p.428-438, 2015. Available from: <http://www.sciencedirect.com/science/ article/pii/S1756464614003958>. Accessed: Dec. 05, 2015. doi: 10.1016/j.jff.2014.12.016.

CALO, J.R. et al. Essential oils as antimicrobials in food systems - A review. Food Control, v.54, p.111119, 2015. Available from: <http://www.sciencedirect.com/science/ article/pii/S0956713515000456>. Accessed: Jan. 06, 2016. doi: 10.1016/j.foodcont.2014.12.040.

CARVALHO, R.J. et al. Comparative inhibitory effects of Thymus vulgaris L. essential oil against Staphylococcus aureus, Listeria monocytogenes and mesophilic starter co-culture in cheesemimicking models. Food Microbiology, v.52, p.59-65, 2015. Available from: $<$ http://www.sciencedirect.com/science/article/pii/ S0740002015001252>. Accessed: Jan. 06, 2016. doi: 10.1016/j. fm.2015.07.003.

CAVA, R. et al. Antimicrobial activity of clove and cinnamon essential oils against Listeria monocytogenes in pasteurized milk. Journal of Food Protection, v.70, p.2708-2934, 2007. Available from: <http:// www.ncbi.nlm.nih.gov/pubmed/18095427>. Accessed: Oct. 02, 2015.

COSTA, D.C. et al. Advances in phenolic compounds analysis of aromatic plants and their potential applications. Trends in Food Science \& Technology, v.45, p.336-354, 2015. Available from: $<$ http:// www.sciencedirect.com/science/article/pii/S0924224415001521>. Accessed: Nov. 23, 2015. doi: 10.1016/j.tifs.2015.06.009.

DAGDELEN, S. et al. Volatile composition, antioxidant and antimicrobial activities of herbal plants used in the manufacture of van herby (OTLU) cheese. Journal of Food Processing and Preservation, v.38, p.1716-1725, 2014. Available from: <http:// onlinelibrary.wiley.com /doi/10.1111/jfpp.12134/epdf > . Accessed: Oct. 22, 2015. doi: 10.1111/jfpp.12134.

DIAO, W.R. et al. Chemical composition, antibacterial activity and mechanism of action of essential oil from seeds of fennel (Foeniculum vulgare Mill.). Food Control, v.35, p.109-116, 2014. Available from: <http://www.sciencedirect.com/science/article/pii/ S0956713513003393>. Accessed: Nov. 04, 2015. doi: 10.1016/j. foodcont.2013.06.056. 
DIMA, C.; DIMA, S. Essential oils in foods: extraction, stabilization, and toxicity. Current Opinion in Food Science, v.5, p.29-35, 2015. Available from: <http://www.sciencedirect. com/science/article/pii/S2214799315000958 > . Accessed: Feb. 02, 2016. doi: $10.1016 /$ j.cofs.2015.07.003.

ELGUEA-CULEBRA, G.O. et al. In vitro antifungal activity of residues from essential oil industry against Penicillium verrucosum, a common contaminant of ripening cheeses. LWT - Food Science and Technology, v.73, p.226-232, 2016. Available from: <http:// www.sciencedirect.com/science/article/pii/S0023643816303401>. Accessed: Nov. 16, 2016. doi: 10.1016/j.lwt.2016.06.008.

F.D.A. (Food and Drug Administration). Substances generally recognized as safe. Eletronic code of federal regulations 21 cfr 182. U.S. GOVERNMENT PUBLISHING OFFICE, 2016. Available from: <https://www.gpo.gov/fdsys/pkg/CFR-2016-title21-vol3/pdf/ CFR-2016-title21-vol3-sec182-1.pdf>. Accessed: May. 12, 2016.

FORLIN, A.M. Plantas aromática: diferentes formas de multiplicación. Informe Técnico-Série Extension Rural, INTA. El Colorado, 2012. Available from: <https://huertasescolares.files. wordpress.com/2010/02/plantas-aromaticas-el-colorado.pdf $>$. Accessed: Oct. 15, 2016.

GAMMARIELLO, D. et al. Effects of natural compounds on microbial safety and sensory quality of Fior di Latte cheese, a typical Italian cheese. Journal of Dairy Science, v.91, p.41384146, 2008. Available from: <http://www.sciencedirect.com/ science/article/pii/S0022030208709603>. Accessed: Oct. 02, 2015. doi: $10.3168 /$ jds.2008-1146.

GANDOMI, H. et al. Effect of Zataria multiflora Boiss. essential oil on growth and aflatoxin formation by Aspergillus flavus in culture media and cheese. Food and Chemical Toxicology, v.47, p.2397-2400, 2009. Available from: <http://www.sciencedirect. com/science/article/pii/S0278691509002531>. Accessed: Oct. 02, 2015. doi: 10.1016/j.fct.2009.05.024.

GILL, A.O.; HOLLEY, R.A. Disruption of Escherichia coli, Listeria monocytogenes and Lactobacillus sakei cellular membranes by plant oil aromatics. International Journal of Food Microbiology, v.108, p.1-9, 2006a. Available from: <http:// www.sciencedirect.com/science/article/pii/S0168160505005684>. Accessed: Oct. 02, 2015. doi: 10.1016/j.ijfoodmicro.2005.10.009.

GILL, A.O.; HOLLEY, R.A. Inhibition of membrane bound ATPases of Escherichia coli and Listeria monocytogenes by plant oil aromatics. International Journal of Food Microbiology, v.111, p.170-174, 2006b. Available from: <http://www.sciencedirect. com/science/article/pii/S0168160506002844>. Accessed: Jan. 05, 2015. doi: 10.1016/j.ijfoodmicro.2006.04.046.

GOVARIS, A. et al. Antibacterial activity of oregano and thyme essential oils against Listeria monocytogenes and Escherichia coli O157:H7 in Feta cheese packaged under modified atmosphere. LWT - Food Science and Technology, v.44, p.1240-1244, 2011. Available from: <http:// www.sciencedirect.com/science/article/pii/S0023643810003440>. Accessed: Oct. 02. 2015. doi: 10.1016/j.lwt.2010.09.022.

GUTIERREZ, J. et al. The antimicrobial efficacy of plant essential oil combinations and interactions with food ingredients. International Journal of Food Microbiology, v.124, p.91-97, 2008. Available from: <http://www.sciencedirect.com/science/ article/pii/S0168160508001177>. Accessed: Oct. 03, 2015. doi: 10.1016/j.ijfoodmicro.2008.02.028.
HAN, J. et al. Effect of polyphenolic ingredients on physical characteristics of cheese. Food Research International, v.44, p.494-497, 2011. Available from: <http://www.sciencedirect.com/ science/article/pii/S0963996910004011>. Accessed: Nov. 08, 2015. doi: 10.1016/j.foodres.2010.10.026.

HASSANIEN, M.F.R. et al. Soft cheese supplemented with black cumin oil: impact on foodborne pathogens and quality during storage. Saudi Journal of Biological Sciences, v.21, p.280-288, 2014. Available from: <http://www.sciencedirect.com/science/ article/pii/S1319562X13000946>. Accessed: Oct. 08, 2015. doi: 10.1016/j.sjbs.2013.10.005.

LIBRÀN, C.M. et al. Potential application of aromatic plant extracts to prevent cheese blowing. World Journal of Microbiology and Biotechnoly, v.29, p.1179-1188, 2013. Available from: <http:// link.springer.com/article/10.1007/s11274-013-1280-x>. Accessed: Nov. 05, 2015. doi: 10.1007/s11274-013-1280.

OLIVEIRA, T.L.C. et al. Natural antimicrobials as additional hurdles to preservation of foods by high pressure processing. Trends in Food Science \&Tecnhology, v.45, n.1, p.60-85, 2015. Available from: $<$ http:// www.sciencedirect.com/science/article/pii/S0924224415001417>. Accessed: Oct. 02, 2015. doi:10.1016/j.tifs.2015.05.007.

MARCIAL, G.E. et al. Influence of oregano essential oil on tradional Argentinean cheese elaboration: effect on latic starter cultures. Revista Argentina de Microbiología, v.48, n.3, p.229235, 2016. Available from: <http://www.sciencedirect.com/ science/article/pii/S03257540116300116>. Accessed: Nov. 16, 2016. doi: 10.1016/j.ram.2016.04.006.

MORO, A. et al. Dairy matrix effect on the transference of rosemary essential oil compounds during cheese making. Journal of the Science of Food and Agriculture, v.95, p. 1507-1513, 2015. Available from: <http://onlinelibrary.wiley.com/doi/10.1002/ jsfa.6853/epdf $>$. Accessed: Oct. 03, 2015. doi: 10.1002/jsfa.6853.

MORO, A. et al. Mycotoxicogenic fungal inhibition by innovative cheese cover with aromatic plants. Journal of the Science of Food and Agriculture, v.93, p.1112-1118, 2013. Available from: $<\mathrm{http}: / /$ onlinelibrary.wiley.com/doi/10.1002/jsfa.5859/epdf $>$. Accessed: Oct 03 , 2015. doi: $10.1002 /$ jsfa. 5859 .

NEGI, P.S. Plant extracts for the control of bacterial growth: efficacy, stability and safety issues for food application. International Journal of Food Microbiology, v.156, p.7-17, 2012. Available from: <http://www.sciencedirect.com/science/ article/pii/S0168160512001250>. Accessed: Oct. 09, 2015. doi: 10.1016/j.ijfoodmicro.2012.03.006.

SHAN, B. et al. Potential application of spice and herb extracts as natural preservatives incheese. Journal of Medicinal Food,v.14,p.284-290, 2011. Available from: <http://www. ncbi.nlm.nih.gov/pubmed/21142945>. Accessed: Oct. 02, 2015. doi: 10.1089/jmf.2010.0009.

SINDHU, S. et al. Chemoprevention by essential oil of turmeric leaves (Curcuma longa L.) on the growth of Aspergillus flavus and aflatoxin production. Food and Chemical Toxicology, v.49, p.1188-1192, 2011. Available from: <http://www.sciencedirect. com/science/article/pii/S0278691511000585>. Accessed: Oct. 02, 2015. doi: 10.1016/j.fct.2011.02.014.

SMITH-PALMER,A. etal. Influence of subinhibitory concentrations of plant essential oils on the production of enterotoxins A and B and $\alpha$-toxin by Staphylococcus aureus. Journal Medical 
Microbiology, v.53, p.1023-1027, 2004. Available from: <http:/ www.ncbi.nlm.nih.gov/pubmed/15358826>. Accessed: Nov. 06, 2015. doi: 10.1099/jmm.0.45567-0.

TAYEL, A.A. et al. Foodborne pathogens prevention and sensory attributes enhancement in processed cheese via flavoring with plant extracts. Journal of Food Science, v.80, p.M2886-M2891, 2015. Available from: $<$ http://onlinelibrary.wiley.com/doi/10.1111/17503841.13138/epdf>. Accessed: Dec. 05, 2015. doi: 10.1111/17503841.13138 .

VÁZQUEZ, B.I. et al. Inhibitory effects of eugenol and thymol on Penicillium citrinum strains in culture media and cheese. International Journal of Food Microbioly, v.67, p.157-163, 2001. Available from: <http://www.sciencedirect.com/science/
article/pii/S0168160501004299>. Accessed: Oct. 02, 2015. doi: 10.1016/S0168-1605(01)00429-9.

ZHANG, Y. et al. Antibacterial activity and mechanism of cinnamon essential oil against Escherichia coli and Staphylococcus aureus. Food Control, v.59, p.282-289, 2016. Available from: <http:// www.sciencedirect.com/science/article/pii/S0956713515300219>. Accessed: Oct. 06, 2015. doi: 10.1016/j.foodcont.2015.05.032.

WAHBA, N.M. et al. Antimicrobial effects of pepper, parsley, and dill and their roles in the microbiological quality enhancement of traditional Egyptian Kareish cheese. Foodborne Pathogens and Disease, v.7, p.411-418, 2010. Available from: <http://online. liebertpub.com/doi/pdf/10.1089/fpd.2009.0412>. Accessed: Oct. 02, 2015. doi: $10.1089=$ fpd.2009.0412. 